\title{
A Direct Multiple Shooting Method for Missile Trajectory Optimization with The Terminal Bunt Manoeuvre
}

\author{
S. Subchan
}

\begin{abstract}
Numerical solution of constrained nonlinear optimal control problem is an important field in a wide range of applications in science and engineering. The real time solution for an optimal control problem is a challenge issue especially the state constrained handling. Missile trajectory shaping with terminal bunt manoeuvre with state constaints is addressed. The problem can be stated as an optimal control problem in which an objective function is minimised satisfying a series of constraints on the trajectory which includes state and control constraints. Numerical solution based on a direct multiple shooting is proposed. As an example the method has been implemented to a design of optimal trajectory for a missile where the missile must struck the target by vertical dive. The qualitative analysis and physical interpretation of the numerical solutions are given.
\end{abstract}

Keywords—terminal bunt manoeuvre, missile trajectory, direct multiple shooting

Abstrak-Penyelesain numerik permasalahan kendali optimal taklinier dengan kendala adalah area penting dalam berbagai terapan sains dan rekayasa. Permasalahan kendali optimal waktu online dimana variabel state terkendala merupakan permasalahan yang menarik dan menantang. Dalam Paper ini dibahas pembentukan lintasan peluru kendali dengan manuver menghunjam ketika mendekati target dengan kendala pada variabel state. Permasalahan lintasan peluru kendali dimodelkan sebagai permasalahan kendali optimal dengan fungsi tujuan meminumkan waktu dengan kendala pada variabel state dan kendali. Penyelesaian numerik berdasar metoda langsung tembakan beruntun diterapkan untuk permasalahan kendali optimal. Sebagai contoh, metoda diterapkan untuk merekayasa lintasan peluru kendali dengan lintasan menghunjam ketika mendekati target. Pada paper ini dibahas hasil komputasi dengan penyelesaiannya dianalisis secara kualitatif dan dibahas interpretasi fisisnya.

Kata Kunci-terminal bunt manoeuvre, trayek missile, direct multiple shooting

\section{INTRODUCTION}

$\mathrm{N}$ umerical solution of the optimal control problem can be categorised into two main approaches. The first approach corresponds to the direct method which is based on the discretisation of state and/or control variables over time, so that a Nonlinear Problem (NLP) solver can be used. The second approach corresponds to the indirect method. The first step is the formulation of the appropriate Two-Point Boundary Value Problem (TPBVP) and the second step is solving the TPBVP numerically.

Direct methods are based on the transformation of the original optimal control problem into a NLP by discretising the state and/or control history and then solving the resulting NLP problem. A variety of direct methods has been developed and applied for solving an optimal control problem. Gradient algorithms were proposed by [1] and [2]. A state constrained optimal control problem using a gradient algorithm and applied it for some problems [3]. [4] Reintroduced the direct transcription approach, by discretising the dynamic equations using a collocation method. A cubic polynomial is used to approximate the state variables and linear interpolation for the control variables. The collocation scheme was originally used by [5] to solve TPBVP. [6] Introduced an approach based on the representation of the dynamical system in terms of

S. Subchan is with Department of Mathematics, FMIPA, Institut Teknologi Sepuluh Nopember, 60111, Surabaya, Indonesia. E-mail: subchan@matematika.its.ac.id differential inclusions. This method employs the concepts of hodograph space and attainable sets [6-7].

The indirect approach for the optimal control problem is based on a generalisation of the calculus of variations. Necessary conditions for an extremum are derived by considering the first variation of the performance index with constraints adjoined in the manner of Lagrange. Since the setting is infinite-dimensional, the familiar Lagrange multipliers are now functions of time, and are called co-states in analogy to the system state. While in the finite-dimensional case the multipliers are computed from algebraic equations, the co-states obey a differential equation. The necessary conditions entail both the original differential equations of the underlying dynamical system and the associated adjoin differential equations of the co-states. The end result is a TPBVP which is made up of the state and co-states equations together with the initial and terminal conditions. The approach is called indirect, because the optimal control is found by solving the auxiliary TPBVP, rather than by a direct focus on the original problem.

This paper focuses on the direct multiple shooting approaches solving an example of the terminal bunt shaping problem for a cruise missile with minimum time flight. The terminal bunt shaping is a complex manoeuvre where the missile must fly as low as possible to hide from radar and when it closes to the target the missile must climb and then struck the target by vertical dive. In this paper the terminal bunt manoeuvre is constrained by the normal acceleration constraint which is active during the diving manoeuvre. 


\section{METHOD}

The optimal control problem is solved by numerical method using a direct multiple shooting. Direct multiple shooting to trajectory optimization is generally based on the discretisation of control and/or state variables. The basic idea of the direct multiple shooting methods is to transform the original optimal control problem into nonlinear programming problem by coupling the control parameterisation with a multiple shooting discretisation of the state variables [8-10]. The control can be approximated by piecewise functions and the state variables are approximated at the shooting nodes $t_{i}$ (see Figure 1). The initial value $\mathrm{x}\left(t_{i}\right)$ for the state variables at nodes $t_{i}$ must be guessed. Then in each interval the state equations must be integrated individually from $t_{i}$ to $t_{\mathrm{i}+1}$.

In addition, the continuity conditions (matching conditions) must be satisfied which require that on each differential node the values $\mathrm{x}\left(t_{\mathrm{i}+1}\right)$ should equal the final value of the preceding trajectory.

Consider now the following boundary value problem.

$\dot{x}(t)=f[x(t), u(t)], r\left[x\left(t_{0}\right), x\left(t_{\mathrm{f}}\right)\right]=0$

Where $\dot{\mathrm{x}}(\mathrm{t})$ is the dynamic system and $r$ is the boundary conditions. The basic idea of the multiple shooting is to find simultaneously the values

$s_{\mathrm{i}}=x\left(t_{\mathrm{i}}\right), \mathrm{i}=1, \cdots, \mathrm{n}$

Where $S_{\mathrm{i}}$ is the initial value at node $\mathrm{i}$ and for the solution of the boundary value problems (1) at the discretised nodes

$t_{0}<t_{1}<\ldots<t_{1}=t_{\mathrm{f}}$

We assume that the discretisation nodes for the control parameterisation are the same as for the state parameterisation. Suppose $x\left[t ; s_{\mathrm{i}}\right]$ is the solution of the initial value problem:

$\dot{x}=f[t, x, u(t)], x\left(t_{\mathrm{i}}\right)=s_{\mathrm{i}}, t \in\left[t_{\mathrm{i}}, t_{\mathrm{i}+1}\right]$

The problem now is to find the vector $s_{\mathrm{i}}, \mathrm{i}=0,1, \cdots, \mathrm{n}$ such that the function $x(t)$ pieced together, continuously, by the following Initial Value Problem (IVP) solutions:

$x(t):=x\left[t ; s_{\mathrm{i}}\right]$ for $t \in\left[t_{\mathrm{i}}, t_{\mathrm{i}+1}[, \mathrm{i}=0,1, \ldots, \mathrm{n}-1\right.$.

$x\left(t_{\mathrm{n}}\right):=s_{\mathrm{n}}$

In addition, the boundary condition $r\left[x\left(t_{\mathrm{O}}\right), x\left(t_{\mathrm{f}}\right)\right]=0$ must be satisfied by $x(t)$. Hence, the boundary value problem (5) is solved on the whole interval. Consider now the following equation $X(s)$ :

$$
X(s)=\left(\begin{array}{c}
x\left[t_{1} ; s_{0}\right]-s_{1} \\
x\left[t_{2} ; s_{1}\right]-s_{2} \\
\vdots \\
x\left[t_{\mathrm{n}} ; s_{\mathrm{n}-1}\right]-s_{\mathrm{n}} \\
r\left[x\left(s_{0}\right), x\left(s_{\mathrm{n}}\right)\right]
\end{array}\right)=0
$$

where the unknown variables

$$
s=\left(\begin{array}{c}
s_{0} \\
s_{1} \\
\vdots \\
s_{\mathrm{n}-1} \\
s_{\mathrm{n}}
\end{array}\right)
$$

must be found. The optimal control problem now can be rewritten as an NLP problem.

$$
\min J(s)=\sum_{i=0}^{n-1} J_{i}\left(s_{\mathrm{i}}\right)
$$

subject to

$x\left[t_{i+1} ; s_{i}\right]-s_{i+1}=0, \quad i=0,1, \ldots, n-1$

$r\left[x\left(s_{0}\right), x\left(s_{n}\right)\right]=0$

The path constraints are transformed into vector inequality constraints at the multiple shooting nodes. The NLP problem result can then be solved by an established NLP solver, SNOPT [11].

\section{RESULT AND DISCUSSION}

\section{A. Mathematical Model}

This paper studies the dynamic equations of a point mass missile moving in the vertical plane over flat nonrotating earth. The dynamic equations are taken from [12] as follows

$$
\begin{aligned}
& \dot{\gamma}=\frac{T-D}{m V} \sin \alpha+\frac{L}{m V} \cos \alpha-\frac{g \cos \gamma}{V} \\
& \dot{V}=\frac{T-D}{m} \cos \alpha-\frac{L}{m} \sin \alpha-g \sin \gamma \\
& \dot{x}=V \cos \gamma \\
& \dot{h}=V \sin \gamma
\end{aligned}
$$

where $t$ is the actual time, $t_{0} \leq t \leq t_{f}$ with $t_{0}$ as the initial time and $t_{f}$ as the final time. The state variables are the flight path angle $\gamma$, speed $V$, horizontal position $x$ and altitude $h$ of the missile. The thrust magnitude $T$ and the angle of attack $\alpha$ are the two control variables (see Figure 2). The aerodynamic forces $D$ and $L$ are functions of the altitude $h$, velocity $V$ and angle of attack $\alpha$. The following relationships have been assumed:

\section{B. Axial Aerodynamic Force}

The $\operatorname{drag} D$ is written in the form

$$
\begin{aligned}
& D(h, V, \alpha)=\frac{1}{2} C_{d} \rho V^{2} S_{\text {ref }} \\
& C_{\mathrm{d}}=A_{1} \alpha^{2}+A_{2} \alpha+A_{3}
\end{aligned}
$$

Note that $D$ is not the drag force.

\section{Normal Aerodynamic Force}

The lift $L$ is written in the form

$$
L(h, V, \alpha)=\frac{1}{2} C_{1} \rho V^{2} S_{\text {ref }}
$$$$
C_{l}=B_{1} \alpha+B_{2}
$$

where $\rho$ is air density given by

$$
\rho=C_{1} h^{2}+C_{2} h+C_{3}
$$

and $S_{\text {ref }}$ is the reference area of the missile; $m$ denotes the mass and $g$ the gravitational constant, see also Table 1 . Note that $L$ is not the drag force.

In addition, constraints are defined as follows:

- State path constraints

$V_{\min } \leq V \leq V_{\max }$

$h_{\text {min }} \leq h$

- Control path constraint

$T_{\min } \leq T \leq T_{\max }$

- Mixed state and control constraint

$L_{\text {min }} \leq \frac{L}{m g} \leq L_{\max }$

where $L_{\min }$ and $L_{\max }$ are normalized, see Table 2. 


\section{Objective Function}

The problem is to find the trajectory of a generic cruise missile from the assigned initial state to a final state with the minimum time along the trajectory. The objective can be formulated by introducing the performance criterion:

$$
J=\int_{t_{0}}^{t_{f}} \mathrm{~d} t
$$

The computational results of the terminal bunt manoeuvre problem are obtained using a direct multiple shooting. In this simulation the missile is assumed to be launched horizontally from the altitude $h(0)=30 \mathrm{~m}$. The boundary conditions are given as follows:

$$
\begin{array}{ll}
\gamma(0)=0 \mathrm{deg} & \gamma\left(t_{f}\right)=-90 \mathrm{deg} \\
V(0)=272 \mathrm{~m} / \mathrm{s} & V\left(t_{f}\right)=310 \mathrm{~m} / \mathrm{s} \\
x(0)=0 \mathrm{~m} & x\left(t_{f}\right)=10000 \mathrm{~m} \\
h(0)=30 \mathrm{~m} & h\left(t_{f}\right)=0 \mathrm{~m}
\end{array}
$$

\section{E. Qualitative Analysis}

The numerical solution based on the direct multiple shooting are shown on Figure 3 to 8. Based on Figure 3 to 8 , an attempt is made to analyse characteristic arcs of the trajectory, classify them according to the constraints active on them, and suggest physical/mathematical explanations for the observed behavior.

The trajectory is split into two subintervals: level climbing and diving. Each of the trajectory arcs corresponding to the subintervals is now discussed in turn.

1. First arc: climbing

The missile must climb eventually in order to achieve the final condition of the flight path angle $\gamma_{t f}$ Figure 5 shows that the missile climbs directly at the beginning of launch. The thrust constraint is the only active constraint at the beginning of climbing. At the beginning of ascent

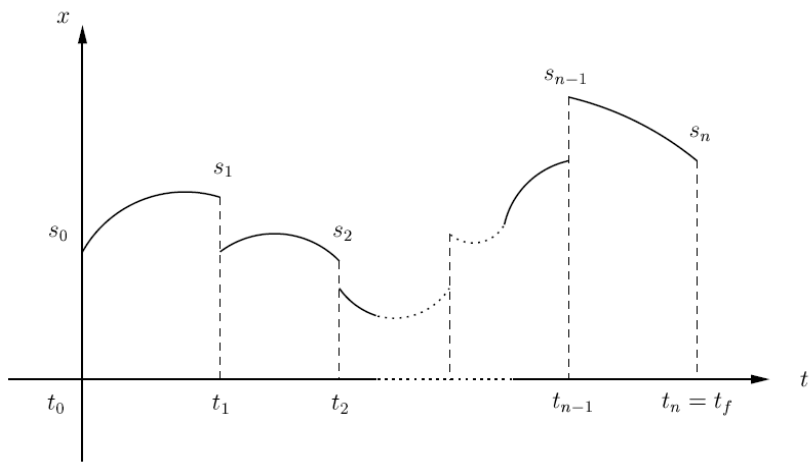

Figure 1. Multiple shooting approach [13] the flight-path angle must increase to facilitate a nose up motion.

During this time, The speed keeps increasing and then decreasing while the altitude $h$ increase. While rapid climbing is necessary, the missile should also turn over to begin its dive as soon as possible, so that the excess of altitude (above $h_{\min }$ ) is minimised.

2. Second arc: diving

At the end of the manoeuvre the missile should hit the target with a certain speed $V_{f}$. The speed during turnover is smaller than final speed $V_{f}$ so the speed must increase and hence the thrust keeps on the maximum value. It means the thrust will facilitate the missile's arrival on the target as soon as possible. Thus the thrust is on the maximum value overall manoeuvre.

At the beginning of diving the minimum normal acceleration constraints is active and keeps on saturation until the missile hits the target (see Figure 6). Obviously, the altitude goes down to reach the target $(\gamma<0 \rightarrow \dot{h}<0)$, while the speed goes up to satisfy the terminal speed condition $V_{f}$. Finally, the missile satisfies the terminal condition of the manoeuvre approximately $t_{\mathrm{f}}$ after firing.

\section{CONCLUSION}

The direct method approach based on the direct multiple shooting is used to solve the trajectory of missile with terminal bunt manoeuvre with state and control constraints. The performance of the direct multiple shooting is more accurate then the direct collocation. Furthermore for the future research the indirect method can be used to verify the accuracy of the direct multiple shooting, notice there is a pure state constraint which is challenging for the indirect method.

The qualitative analysis shows that the optimal trajectory is split into two subintervals. The first arc is level climbing. The missile must climb in order to achieve the final condition. The thrust keeps on the maximum value while the altitude increases to gain enough position for diving in the next arc.

The second arc is diving. The missile must gain the power to reach the target therefore the speed increase rapidly since the initial diving speed is lower than the final speed. The normal acceleration is saturated on the minimum value for this arc.

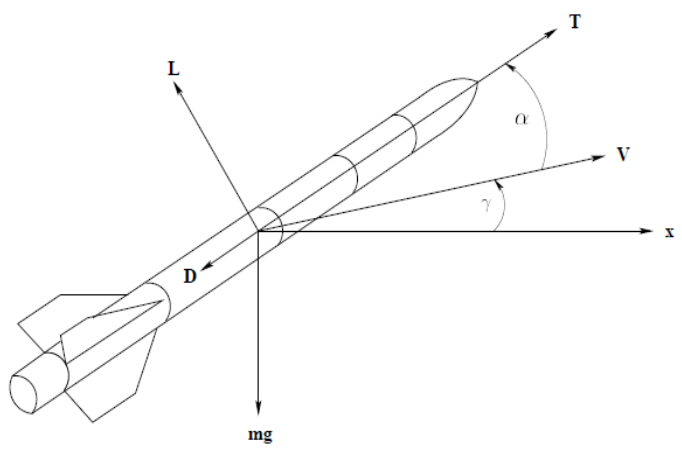

Figure 2. Definition of missile axes and angles [12] 


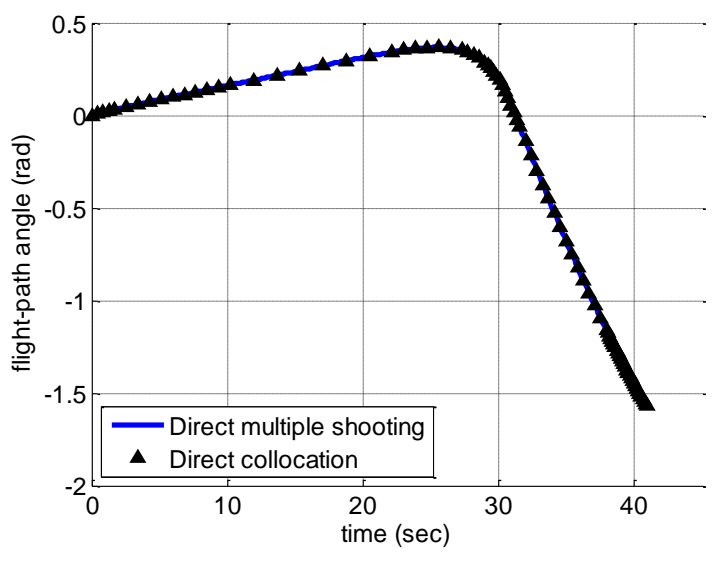

Figure 3. Flight-path angle versus time histories

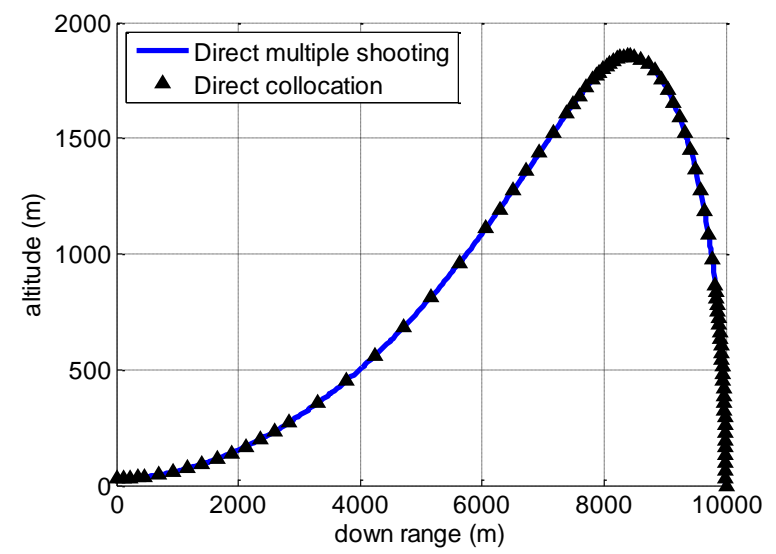

Figure 5. Altitude versus down-range histories

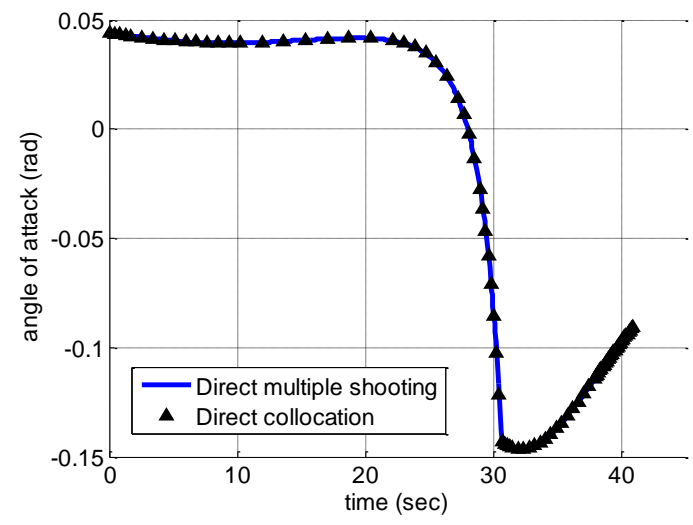

Figure 7. Angle of attack versus time histories

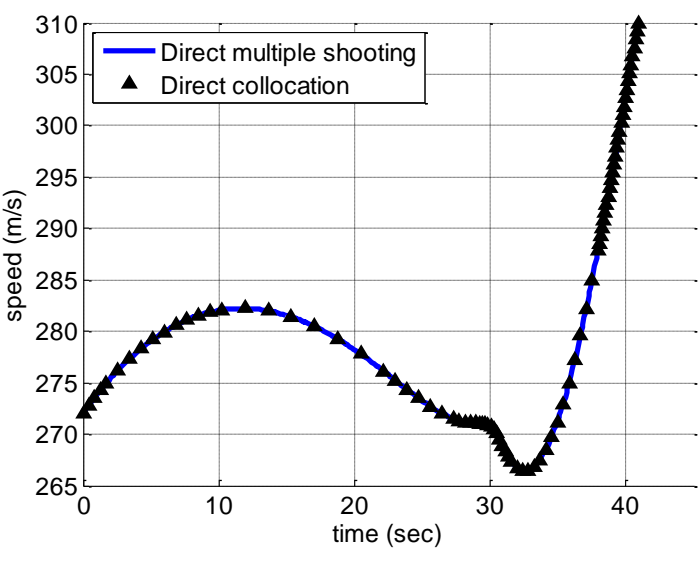

Figure 4. Speed versus time histories

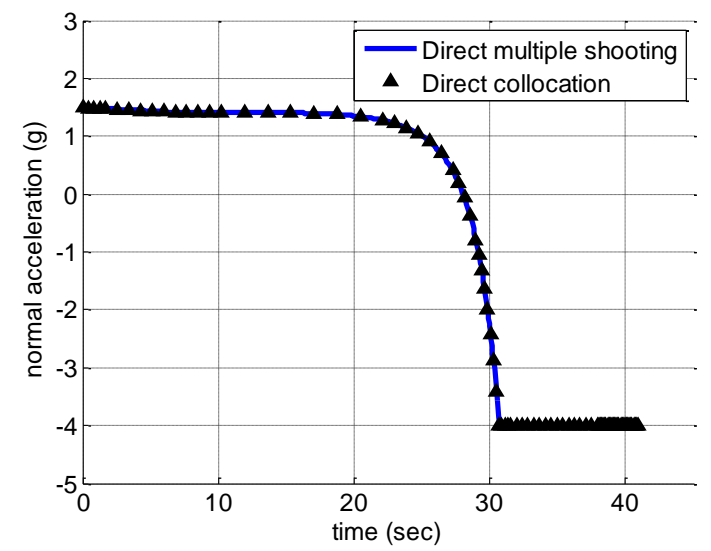

Figure 6. Normal acceleration versus time histories

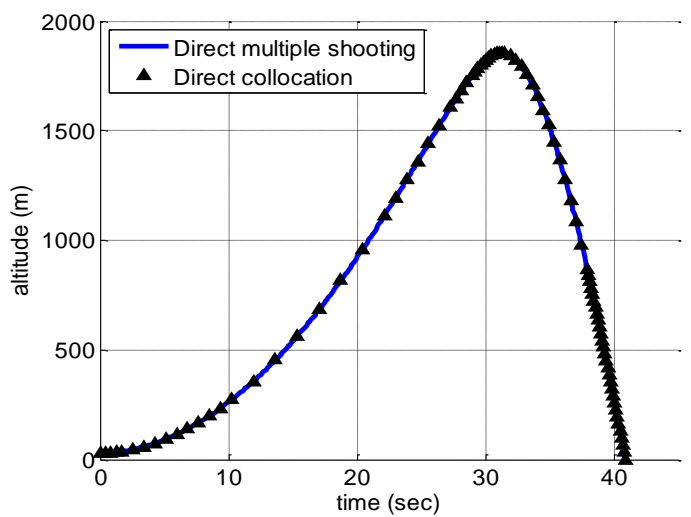

Figure 8. Angle of attack versus time histories

TABLE 1.

PHYSICAL MODELLING PARAMETERS

\begin{tabular}{ccc}
\hline Quantity & Value & Unit \\
\hline$m$ & 1005 & $\mathrm{~kg}$ \\
$g$ & 9.81 & $\mathrm{~m} / \mathrm{s}^{2}$ \\
$S_{\text {ref }}$ & 0.3376 & $\mathrm{~m}^{2}$ \\
$A_{1}$ & -1.9431 & \\
$A_{2}$ & -0.1499 & \\
$A_{3}$ & 0.2359 & \\
$B_{1}$ & 21.9 & \\
$B_{2}$ & 0 & \\
$C_{1}$ & $3.31210^{-9}$ & $\mathrm{~kg} \mathrm{~m}^{-5}$ \\
$C_{2}$ & $-1.14210^{-4}$ & $\mathrm{~kg} \mathrm{~m}^{-4}$ \\
$C_{3}$ & 1.224 & $\mathrm{~kg} \mathrm{~m}^{-3}$ \\
\hline
\end{tabular}


TABLE 2.

\begin{tabular}{ccc}
\multicolumn{3}{c}{ BOUNDARY CONDITIONS AND CONSTRAINTS } \\
\hline Quantity & Value & Unit \\
\hline$V_{\min }$ & 200 & $\mathrm{~m} / \mathrm{s}$ \\
$V_{\max }$ & 310 & $\mathrm{~m} / \mathrm{s}$ \\
$L_{\min }$ & -4 & $\mathrm{~g}$ \\
$L_{\min }$ & 4 & $\mathrm{~g}$ \\
$h_{\min }$ & 30 & $\mathrm{~m}$ \\
$T_{\min }$ & 1000 & $\mathrm{~N}$ \\
$T_{\max }$ & 6000 & $\mathrm{~N}$ \\
\hline
\end{tabular}

\section{REFERENCES}

[1] H. J. Kelley, Methods of gradients In Optimization Techniques with Application to Aerospace systems (ed. G. Leitmann), vol. 5, Mathematics in Science and Engineering Academic press, New York, 1962, pp. 206-254.

[2] A. E. Bryson and W. F. Denham, "A steepest ascent method for solving optimum programming problems," ASME Journal of Applied Mechanics Series E," pp. 247-257, 1962.

[3] R. Pytlak, Numerical Methods for Optimal Control Problems with State Constraints vol. 1707 of Lecture Notes in Mathematics. Springer-Verlag, Berlin, Berlin, 1999.

[4] C. R. Hargraves and S. W. Paris, "Direct trajectory optimization using nonlinear programming and collocation", Journal Guidance, Control, and Dynamics, vol. 10, no. 4, 1987, pp. 338-342.

[5] E. D. Dickmanns and K. H. Well, "Approximate solution of optimal control problems using third order Hermite polynomial functions," in Proceedings of the IFIP Technical Conference, Springer-Verlag, 1974, pp. 158-166.

[6] R. R. Kumar and H. Seywald. Fuel-optimal station keeping via
TABLE 3.

PERFORMANCE INDEX FOR THE MiNIMUM TIME PROBLEM FOR THE CASE OF FINAL SPEED $V\left(T_{\mathrm{F}}\right)=310 \mathrm{M} / \mathrm{S}$

\begin{tabular}{ccc}
\hline Method & $\begin{array}{c}\text { Performance index } \\
(\mathrm{sec})\end{array}$ & $\begin{array}{c}\text { No of grid } \\
\text { points }\end{array}$ \\
\hline $\begin{array}{c}\text { Direct multiple } \\
\text { shooting } \\
\begin{array}{c}\text { Direct } \\
\text { collocation }\end{array}\end{array}$ & 40.90257 & 15 \\
\hline
\end{tabular}

differential inclusion. Journal of Guidance, Control, and Dynamics, vol. 18, no. 5, pp. 1156-1162, 1995.

[7] H. Seywald. "Trajectory optimization based on differentia inclusion," Journal of Guidance, Control, and Dynamics, vol. 17, no, 3, pp. 480-487, 1994.

[8] H. B. Keller. Numerical Methods for Two-Point Boundary Value Problems. Dover Publications, New York, 1992.

[9] J. Stoer and R. Bulirsch. Introduction to Numerical Analysis. Springer, New York, 3rd ed, 2002

[10] U. M. Ascher, R. M. M. Mattheij, and R. D. Russel. Numerical Solution of Boundary Value Problem for Ordinary Differential Equations. SIAM, Philadelphia, 1995.

[11] P. E. Gill, W. Murray, and M. H. Wright. "SNOPT: An SQP algorithm for large scale constrained optimization," SIAM Journal on Optimization, vol. 12, no. 4, 2002, pp. 979-1006.

[12] S. Subchan and R. Żbikowski. "Computational optimal control of the terminal bunt manoeuvre - Part 1: Minimum altitude case, “Optimal Control Applications \& Methods, vol. 28, no. 5, 2007, pp. 311-353.

[13] S. Subchan and R. Żbikowski, Computational optimal control: tools and practices, John Wiley and Sons, Chichester, 2009. 